Journal of Engineering and Applied Sciences 14 (Special Issue 8): 10341-10348, 2019

ISSN: 1816-949X

(C) Medwell Journals, 2019

\title{
The Validity of Sandstone Powder of Injana Formation-Upper Miocene in Karbala Governorate for the Purposes of Concrete Industry
}

\author{
Farah A. Alsaady and Jaffar H. Alzubaydi \\ Department of Applied Geology, College of Science, University of Babylon, Babylon, Iraq
}

\begin{abstract}
The results of the physical tests by the grain grading of sandstone samples of the study site showed that most of them are in conform with the requirements of the Iraqi Standard (IQS45/1984), so, they can be used for concrete purposes in their natural state. The results of the specific gravity and absorption ratio of the samples of the study sites showed that they conform to the requirements of the Iraqi and British standard specifications that the values of the specific gravity are between (2.3-2.4). Most of the results of the laboratory tests of the durability test for the soundness test of the samples of the study sites showed their suitability with the requirements of the specifications required for the cement concrete works according to the Iraqi Standard (IQS45/1984) and (ASTM C88-05, 2004). As for the physical tests of cement, the results of the laboratory test showed that the specific surface area (Blane method) exceeded the lower limit of Iraqi Standard (IQS45/1984) where it was $\left(383 \mathrm{~m}^{2} \mathrm{~kg}^{-1}\right)$ which was within the limits of the standard as for the setting time (vacate apparatus), the initial setting was $3 \mathrm{~h}$ and $40 \mathrm{~min}$ and was within the limits of the Standard Iraqi (IQS45/1984) and the secondary setting was $4 \mathrm{~h}$ and $10 \mathrm{~min}$ also was within the limits of the standard above. As for the compressive strength for ( 3,7 days) were within the limits of the above standard which was estimated at (3 days) $\left(288 \mathrm{~kg} \mathrm{~cm}^{-2}\right)$ and at the age of $\left(7\right.$ days) was $\left(342 \mathrm{~kg} \mathrm{~cm}^{-2}\right)$. As for the results of the compressive strength tests, the compressive strength values of the concrete cubes that were created from the study sites samples were shown according to the mixture (1:2:4) and the mixture (1:1.5:3) approximation of the compressive strength values of the samples of sites study as a result of convergence of density of aggregates used in the construction of the concrete mixture and according to the British Standard. The highest value for density was $\left(2410 \mathrm{~kg} \mathrm{~m}^{-3}\right)$, the lowest value for density was $\left(2200 \mathrm{~kg} \mathrm{~m}^{-3}\right)$, the highest compressive strength was $(22.5 \mathrm{MPa})$ and the lowest compressive strength value was $(19.51 \mathrm{MPa})(1: 2: 4)$ mixing. The highest density $\left(2450 \mathrm{~kg} \mathrm{~m}^{-3}\right)$ and the lowest density $\left(2420 \mathrm{~kg} \mathrm{~m}^{-3}\right)$. The compressive strength was the highest value $\left(55.5 \mathrm{~N} \mathrm{~mm}^{-2}\right)$ and the lowest value $\left(49 \mathrm{~N} \mathrm{~mm}^{-2}\right)$. The compressive strength values of the (28 day) concrete cubes are considered to be good for the concrete is unarmed. The results of the mineral and petrographic tests of the sandstone powder sample of the area of the study showed that they contain a group of primary metals that play a large role in the permanence and stability of the concrete (quartz, gypsum, Alpite, calcite). As for the results of the chemical analysis of the tests (organic matter, gypsum content, sulphate content), it was found to be suitable for the requirements for use in the concrete work according to British Standard (B.S. 1337-1990, test 3).
\end{abstract}

Key words: Physical tests, chemical tests, durability tests, strength tests, mineralogical tests, compressive

\section{INTRODUCTION}

Location of the study area: The study area is located at Tar Al-Sayyed cliffs in Karbala governorate at $30 \mathrm{~km}$ west of Karbala city, middle of Iraq. The study area consists of two regions, the first region is located between longitudes $\left(43^{\circ} 47^{\prime} 55^{\prime \prime}-43^{\circ} 46^{\prime} 9^{\prime \prime} \mathrm{E}\right)$ and latitudes $\left(32^{\circ} 30^{\prime} 9^{\prime \prime}-32^{\circ} 28^{\prime} 5^{\prime \prime N}\right)$ with area $\left(42 \mathrm{~km}^{2}\right)$. The second region islocated between longitudes (043 $46^{\prime} 832^{\prime \prime}$ $\left.043^{\circ} 46^{\prime} 702^{\prime \prime} \mathrm{E}\right)$ and latitudes $\left(32^{\circ} 28^{\prime} 893^{\prime \prime}-32^{\circ} 28^{\prime} 450^{\prime \prime} \mathrm{N}\right)$ with area $\left(90 \mathrm{~m}^{2}\right)$ the represents a site map showing the stations of the study area (Al-Basrawi, 1996).

Aims of the study: The study aims at making an engineering geological assessment of sandstone rock in the study area by:
Adentification of the geotechnical properties of sandstone powder in the area of the Al-Tar caves area and comparing it with the Iraqi and international standard specifications. The validity of sandstone powder for the engineering purposes such as concrete works.

\section{MATERIALS AND METHODS}

Data collection stag: All of the available publication about the study area (Journals, theses, reports, geologic map and satellite images) were collected and studied. In order to gain better idea about the Injana formation.

Field work stage: In this stage, there are geological work periods for more than 3 days (25-28st November, 2018)

Corresponding Author: Farah A. Alsaady, Department of Applied Geology, College of Science, University of Babylon, Babylon, Iraq 


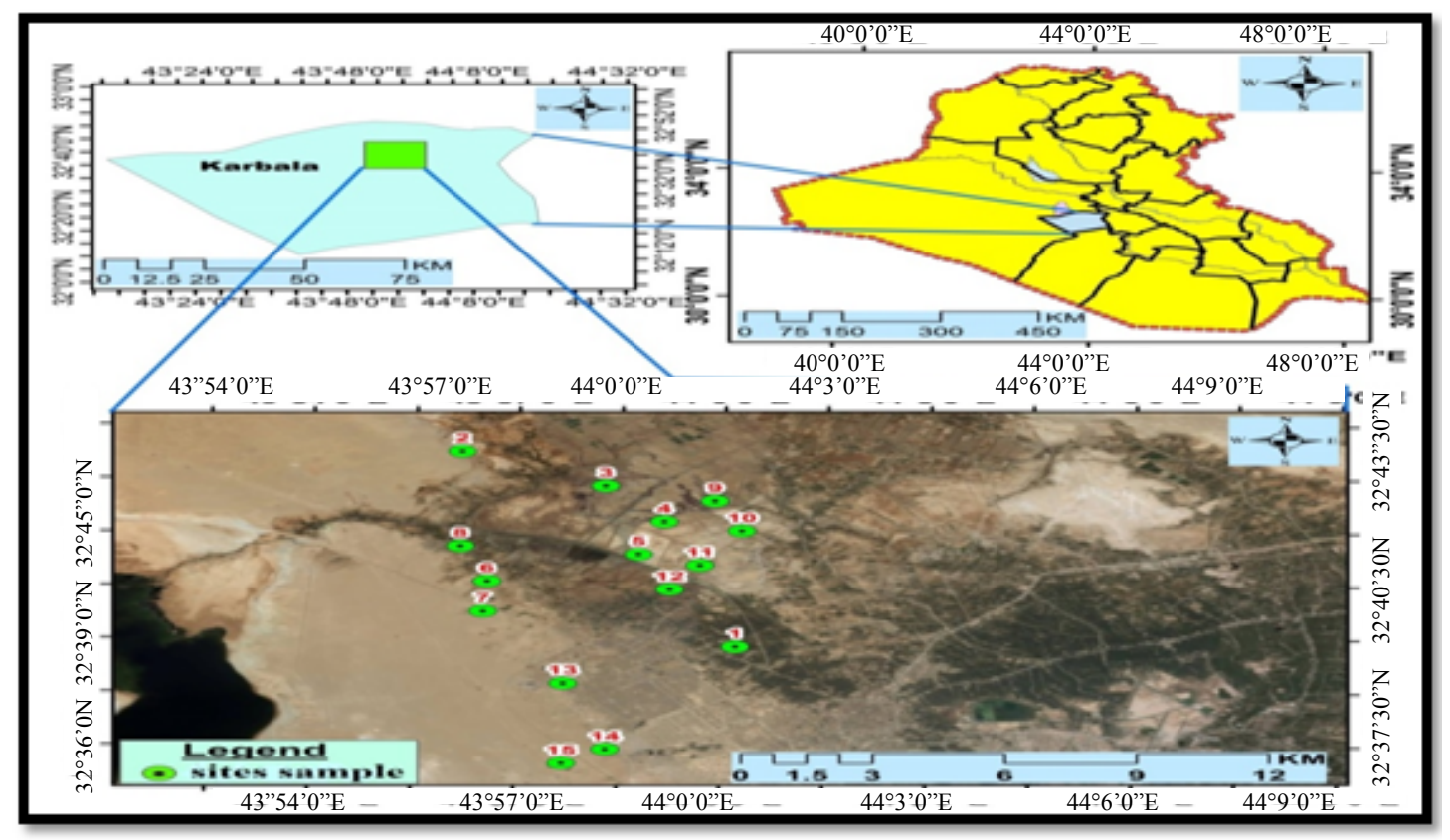

Fig. 1: Location map of the stations for study area

for fifteen sites (stations) to study the geology, stratigraphy, geomorphology in Injana formation (Tar Al-Sayyed) area to collection of rock samples from sandstone station for laboratory tests and engineering description of rock according to the Iraqi and international standard specification.

Laboratory work stage: The performed laboratory tests in this stage includes:

- Physical tests of sandstone powder

- Physical tests of cement

- Chemical tests of cement

- Durability tests

- Soundness test

- Strength tests

- Compressive strength test of cubic concrete

- Chemical tests

- Mineralogical tests

- Petrographic tests

Previous studies: The previous study area has been dealt with by various researchers. He explained, carried out regional geological mapping of Karbala, Najaf area in order to obtain data for final maps of scale 1:250000 and 1:100 000. They divided the stratigraphic sequence into lithologic units and did not refer these units to certain formations.

He explained, carried out fieldwork in order to obtain data for geological map of Karbala province of scale
1:250 000. He explained (Al-Basrawi, 1996), studied hydrogeology of Razzaza lake. He explained, studied the sedimentology and geochemistry of Injana formation rocks in Karbala, Najaf area. He explained, studied the Nfayil formation of the area between Tar Al-Sayyed and Tar Al-Najaf. He explained, mentioned that the lenticular celestite mineralizations are concentrated in clastic rocks of Injana and Dibdibba formations. For geological map of Karbala province of scale 1:250000 of Tar Al-Sayyed.

He explained, studied the geotechnical on the soil of Karbala governorate. He explained, Ahamed (2004) studied the stratigraphy and sedimentology of the Miocene succession-Karbala andNajaf area. He explained (Hassan and Al-Khateeb, 2004), studied the piping phenomenon in the claystone of the Injana formation.

\section{Geology of the study area}

Injana formation (upper miocene): Hassan (2007), studied the stratigraphy of Karbala, Najaf area, central Iraq and divided Injana formation into two main units (Fig. 1).

Lower clastic unit: It consists of alternation of different clastic rocks (claystone, sandstone and siltstone) or admixture of these rocks in different ratios. Thin beds of marly limestone are also recorded, two or three times up to $0.3 \mathrm{~m}$ in thickness, some celesite-bearing beds are recorded in places (Al-Khateeb and Hassan, 2005a, b). Cementing materials are clay or carbonate. Solution of 


\begin{tabular}{|c|c|c|c|c|c|c|c|c|}
\hline \multirow{3}{*}{$\begin{array}{l}\text { Comparison of the } \\
\text { results with the Iraqi } \\
\text { standard No } 45 \text { of } 1984 \\
\text { Sieve size (mm) }\end{array}$} & \multicolumn{8}{|c|}{ Percentage transient of study area models } \\
\hline & \multicolumn{8}{|l|}{ Al-Qattar area } \\
\hline & $\begin{array}{l}\text { Conform gradation } \\
\text { 4area No. } 4 \\
\text { st1 }\end{array}$ & $\begin{array}{l}\text { Not conform to } \\
\text { the standard } \\
\text { st2 }\end{array}$ & $\begin{array}{l}\text { Conform gradation } \\
\text { area No. } 3 \\
\text { st3 }\end{array}$ & $\begin{array}{l}\text { Not conform to } \\
\text { the standard } \\
\text { st } 4\end{array}$ & $\begin{array}{l}\text { Conform gradient } \\
\text { area No. } 4 \\
\text { st5 }\end{array}$ & $\begin{array}{l}\text { Conform gradient } \\
\text { area No. } 4 \\
\text { st } 6 \\
\end{array}$ & $\begin{array}{l}\text { Conform gradient } \\
\text { area No. } 4 \\
\text { st7 }\end{array}$ & $\begin{array}{l}\text { Not conform to } \\
\text { the standard } \\
\text { st8 }\end{array}$ \\
\hline 10 & 100 & 100 & 100 & 100 & 100 & 100 & 100 & 100 \\
\hline 4.75 & 100 & 100 & 100 & 100 & 100 & 100 & 100 & 100 \\
\hline 2.36 & 100 & 85 & 91 & 91 & 100 & 100 & 100 & 91 \\
\hline 1.18 & 100 & 65 & 82 & 80 & 100 & 100 & 100 & 82 \\
\hline 0.6 & 99 & 52 & 69 & 63 & 99 & 98 & 98 & 63 \\
\hline 0.3 & 50 & 43 & 40 & 36 & 49 & 49 & 49 & 36 \\
\hline \multirow[t]{11}{*}{0.15} & 11 & 32 & 9 & 15 & 15 & 12 & 7 & 15 \\
\hline & Al-Tar cavies & & & & & & & \\
\hline & $\begin{array}{l}\text { Confirm the gradient } \\
\text { area No. } 4\end{array}$ & $\begin{array}{l}\text { Confirm the gradient } \\
\text { area No. } 4\end{array}$ & $\begin{array}{l}\text { Not confirm to } \\
\text { the standard }\end{array}$ & $\begin{array}{l}\text { Not confirm to } \\
\text { the standard }\end{array}$ & $\begin{array}{l}\text { Not confirm to } \\
\text { the standard }\end{array}$ & $\begin{array}{l}\text { Confirm the gradient } \\
\text { area No. } 4\end{array}$ & \\
\hline & st9 & st.10 & st11 & st 12 & st13 & st 14 & \multicolumn{2}{|l|}{$\begin{array}{l}\text { area No. } 4 \\
\text { st15 }\end{array}$} \\
\hline & 100 & 100 & 100 & 100 & 100 & 100 & \multicolumn{2}{|l|}{100} \\
\hline & 100 & 100 & 100 & 100 & 100 & 100 & \multicolumn{2}{|l|}{100} \\
\hline & 99 & 100 & 98 & 99 & 91 & 100 & \multirow{2}{*}{\multicolumn{2}{|c|}{99}} \\
\hline & 98 & 98 & 96 & 96 & 82 & 98 & \multirow{2}{*}{\multicolumn{2}{|c|}{$\begin{array}{l}98 \\
97\end{array}$}} \\
\hline & 97 & 90 & 91 & 90 & 69 & 90 & & \\
\hline & 50 & 50 & 78 & 67 & 40 & 50 & \multicolumn{2}{|l|}{50} \\
\hline & 12 & 15 & 24 & 11 & 9 & 15 & \multicolumn{2}{|l|}{12} \\
\hline
\end{tabular}

\begin{tabular}{|c|c|c|c|c|}
\hline Age & FM & Thick & Lithology & Description \\
\hline \multirow{4}{*}{ 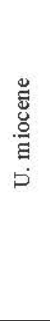 } & \multirow{4}{*}{$\stackrel{\text { 䓵 }}{\Xi}$} & \multirow{4}{*}{$4.2 \mathrm{~m}$} & & Brown sandstone \\
\hline & & & & Pale brown claystone \\
\hline & & & & Marl \\
\hline & & & & Scale: $1 \mathrm{~cm}=100 \mathrm{~m}$ \\
\hline
\end{tabular}

Fig. 2: Represents the stratigraphic section of station No. 1 in Al-Qattara area

diagenetic processes occasionally filled the bedding planes and fractures, forming very thin beds or local aggregate of secondary gypsum. Generally, the claystone and silty claystone or siltstone beds are brown to reddish brown in color, medium tough to tough and cliff-forming, while the sandstones are heterogeneous, micaceous, lithic, cross bedded of grey color. Generally, the sequence shows fining upwards cycles. The thickness of this unit reaches up to $25 \mathrm{~m}$. The succession of this unit shows some lateral and vertical variations (Hassan, 2007).

Upper cave-forming claystone unit: It is informally named the cave-forming claystone unit (Al-Khateeb and Hassan, 2005a, b). It consists of claystone, occasionally silty, brown to reddish brown, conchoidally fractured, massive, tough, cliff-forming, changes laterally or vertically to silty claystone. The thickness of this unit reaches $6.0 \mathrm{~m}$ or more in some places. It has a wide geographic extension along both Tar Al-Najaf and Tar Al-Sayyed for about $170 \mathrm{~km}$. The wide geographic extension of the fine sediments (claystone). Without remarkable lateral lithological variation indicates low energy fluvial depositional current as compared with the lower unit. This unit is highly jointed. It is overlain by highly permeable coarse grained sandstone of Dibdibba formation. Some of these joints are enlarged gradually due to water erosion from the overlying beds forming a well-developed caves which reach $(1 \times 2 \mathrm{~m})$ or more (Al-Khateeb and Hassan, 2005a, b) (Fig. 2 and 3).

\section{Geo technical tests of the study area Physical properties of sandstone powder Grain grading analysis}

Fine aggregate: According to COSQC (1984) standard was performed for fifteen samples of sandstone powder of study area, the eight samples of which are $(1,5,6,7,9$, $10,14,15)$ conform to the fourth grade area of the (COSQC., 1984) Fig. 4 while the three samples conform to the third grade area of the (COSQC., 1984) (Fig. 4) and the other six samples that do not conform with any grade area Table 1 shows the grain grading analysis of sand stone powder of the present study show the specific gravity and absorption ratio value of fine aggregate (sandstone) conform to the limit of (COSQC., 1984) which specific gravity value (2.461) and the absorption ratio value was about (3\%) (Fig. 5). 


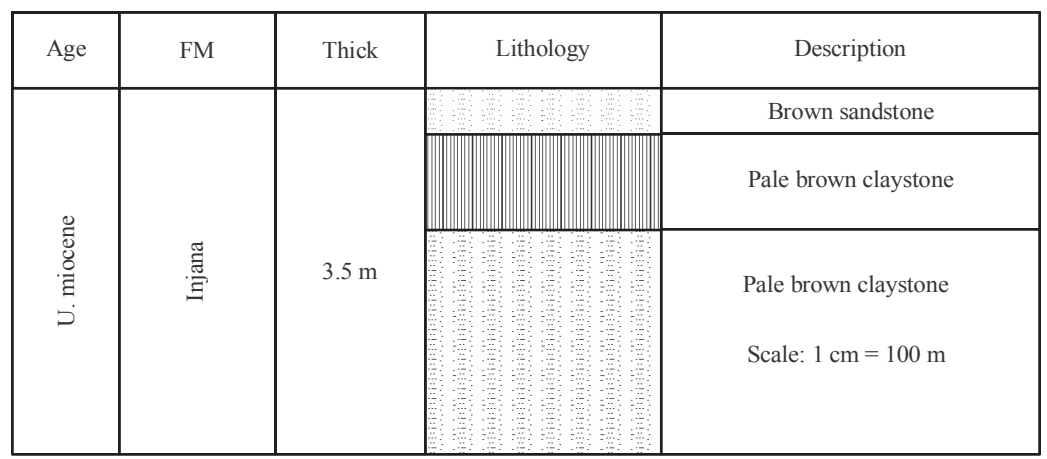

Fig. 3: Represents the stratigraphic section of station No. 9 in Al-Tar caves

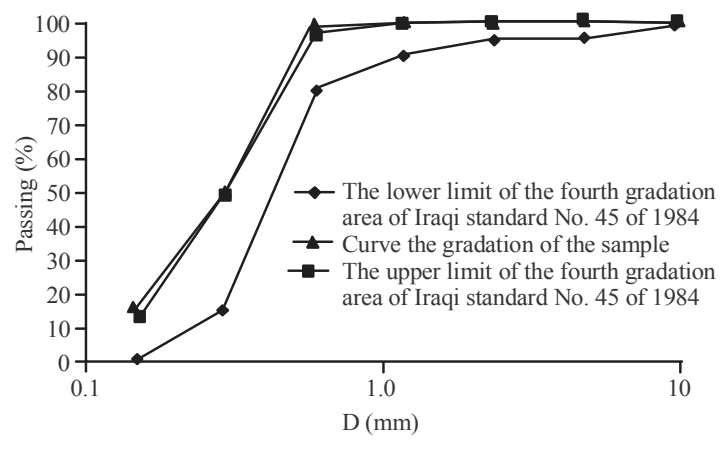

Fig. 4: Grain grading analysis of sandstone powder samples No. $1,5,6,7,9,10,14,15$

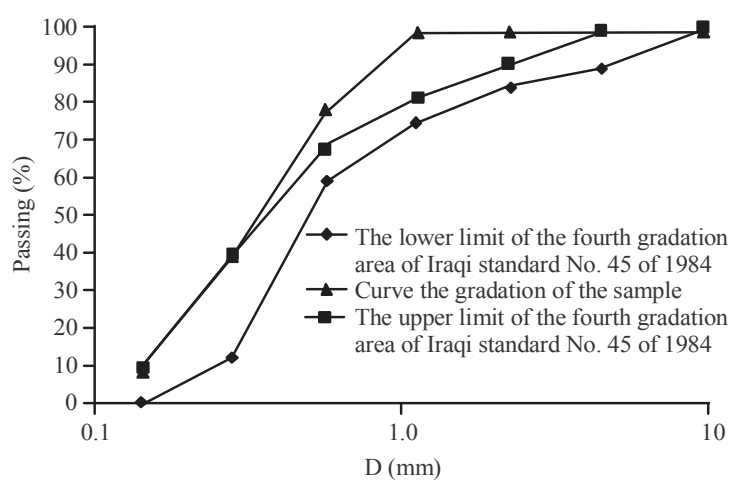

Fig. 5: Grain grand analysis of sandstone powder sample 3

Coarse aggregates: The results of the grain grading of coarse aggregates (crushed Gravel) showed that they conform to the limits of Iraqi Standard (COSQC., 1984). Also, for the specific gravity and absorption of coarse aggregate (gravel), the results of the inspection under Iraqi Standard (COSQC., 1984) showed that they conform to the limits of the mentioned standard which had a specific weight of (2.614) and the absorption rate was about (4\%) (Table 2$)$.
Table 2: The grain grading analysis of coarse aggregate (gravel) Grain grading

Seive size $(\mathrm{mm})$ Passing (\%)

\begin{tabular}{ll}
\hline 7.5 & 100
\end{tabular}

20

10

5

Cement properties

Physical properties of cement: The laboratory test of physical test of cement based on (COSQC., 1984), Table 3 illustrate physical test of cement according (COSQC., 1984).

Chemical properties of cement: The laboratory test of chemical properties of cement based on (COSQC., 1984) Table 4 illustrate chemical test of cement.

\section{Chemical test of sandstone powder}

Sulfate content $\left(\mathrm{SO}_{3}\right)$ : The results of the chemical tests show the sulfate content of sandstone powder samples No. $1,10,11,12,15,3,4,5,6,7,8,9$ conform the requirement of the (COSQC., 1984) and the values of sulfate content does not exceed $(0.5 \%)$ while the sulfate content of sandstone powder samples No. 2, 13 do not conform with (COSQC., 1984) and the value of sulfate content exceed $(5 \%)$, therefor, requires increasing the amount of cement resistant salts in the concert mixture to reduce the impact of sulfate content. The sulfate value of study area Table 4 range from the maximum value in (3.88) in station No. 2 to minimum values $(0.066)$ in station No. 7.

Organic matter content: Organic matter content was perform according (COSQC., 1984). The result of organic matter of the sandstone powder for Injana formation showed that there are no organic matter in the study area Table 4. 
Table 3: The physical test of cement according (COSQC., 1984)

\begin{tabular}{|c|c|c|}
\hline Physical properties & Test results & Limit of Iraqi specification (COSQC., 1984) \\
\hline Specific surface area (Blaine method) $\left(\mathrm{m}^{2} \mathrm{~kg}^{-1}\right)$ & 383 & $\left(230 \mathrm{~m}^{2} \mathrm{~kg}^{-1}\right)$ lower limit \\
\hline \multicolumn{3}{|l|}{ Setting time (vacate apparatus) } \\
\hline Initial setting, $(\mathrm{h}: \min )$ & $3 \mathrm{~h} 40 \mathrm{~min}$ & Not $<45 \mathrm{~min}$ \\
\hline Final setting, (h: min) & $4 \mathrm{~h} 10 \mathrm{~min}$ & Not more than $10 \mathrm{~h}$ \\
\hline \multicolumn{3}{|l|}{ Compressive strength $\left(\mathrm{kg} \mathrm{cm}^{-2}\right)$} \\
\hline For 3 day & 288 & Not $<50 \mathrm{~kg} \mathrm{~cm}^{-2}$ \\
\hline For 7 day & 342 & Not $<230 \mathrm{~kg} \mathrm{~cm}^{-2}$ \\
\hline \multicolumn{3}{|c|}{ Table 4: The chemical test of cement according (COSQC., 1984) } \\
\hline Oxides composition & Content $(\%)$ & Limit of Iraqi specification (COSQC, 1984) \\
\hline $\mathrm{CaO}$ & 60.283 & - \\
\hline $\mathrm{Al}_{2} \mathrm{O}_{3}$ & 3.674 & $8 \% \max$ \\
\hline $\mathrm{SiO}_{2}$ & 20.341 & $21 \% \max$ \\
\hline $\mathrm{Fe}_{2} \mathrm{O}_{3}$ & 5.339 & $5 \% \max$ \\
\hline $\mathrm{MgO}$ & 1.523 & $5 \% \max$ \\
\hline $\mathrm{SO}_{3}$ & 2.514 & $2.5 \% \max$ \\
\hline Loss on Ignition (LOI) & 3.250 & $4 \% \max$ \\
\hline Insoluble material & 0.630 & $1.5 \% \max$ \\
\hline Lime Saturation Factor (LSF) & 0.980 & $(0.66-1.02)$ \\
\hline$\underline{\mathrm{C}_{3} \mathrm{~A}(\%)}$ & 0.715 & $3.5 \max$ \\
\hline
\end{tabular}

Table 5: The chemical test of powder sandstone for the study area

\begin{tabular}{|c|c|c|c|c|}
\hline Location & $\mathrm{SO}_{3}(\%)$ & Gyp (\%) & $\mathrm{OMC}(\%)$ & Limits of max (BS., 1990) \\
\hline \multirow[t]{9}{*}{ Al-Qattara } & 0.179 & 0.38485 & & $\mathrm{SO}_{3} 5 \%$ \\
\hline & 3.880 & 8.342 & & \\
\hline & 0.189 & 0.40635 & & \\
\hline & 0.608 & 1.3072 & ------------ & \\
\hline & 0.438 & 0.9417 & & \\
\hline & 0.075 & 0.16125 & & Gyp $10.75 \%$ \\
\hline & 0.066 & 0.1419 & & \\
\hline & 0.120 & 0.258 & & \\
\hline & 0.082 & 0.1763 & & \\
\hline \multirow[t]{6}{*}{ Al-Tara caves } & 0.413 & 0.88795 & & \\
\hline & 0.818 & 1.7587 & & OMC $2 \%$ \\
\hline & 0.812 & 1.7458 & & \\
\hline & 0.77 & 1.6555 & 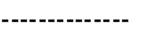 & \\
\hline & 0.62 & 1.333 & & \\
\hline & 0.08 & 0.172 & & \\
\hline
\end{tabular}

Table 6: The durability test

\begin{tabular}{lcccc}
\hline Test & Station No. & Type of sample & Test result (\%) & Limit of Iraqi specification (COSQC., 1984) \\
\hline AL-Qattara & 2 & Stone & 4.180 & Limit maximum 18\% \\
& 3 & & 4.180 & \\
Al-Tar caves & 4 & & 23.000 & \\
& 10 & & 17.000 & \\
& 11 & 20.5 & \\
\hline
\end{tabular}

Gypsum content: The results of the chemical test showed that the gypsum content of sandstone powder were conform with (BS., 1990) and which does not exceed $(10.75 \%)$. The gypsum content values of study area, Table 5 range from the maximum value is (1.7587) in station No. (11) to the minimum value is $(0.162)$ industry No. (6).

\section{Durability tests}

Soundness test: Soundness test was performed according to ASTM. (2004) and COSQC. (1984) for some sampler of sandstone powder for Injana formation. The results of soundness test of Al-Qattara area, especially, station No. $(2,3,4)(2,3)$ has reached $(4.18 \%)$ and $(4)$ is
(23\%), respectively while the results of soundness test of Al-Tar caves, especially, station No. 10, 11, 12 has reached $(17,20.5,22.3 \%)$, respectively while the percentage of weight loss for fine aggregates should not exceed $(10 \%)$ in sodium sulphate solution and $(15 \%)$ in magnesium sulphate solution. Thus, the representative models of the study area are suitable for use in concrete works (Table 6).

\section{RESULTS AND DISCUSSION}

\section{Strength tests}

Compressive strength test of concrete: Results of the compressive strength of concert for samples based on 
Table 7: Compressive strength test of concrete for the mixture (1:2:4)

\begin{tabular}{lcccc}
\hline Sample No. & Density $\left(\mathrm{kg} \mathrm{m}^{-3}\right)$ & Compressive strength in 7 day $(\mathrm{MPa})$ & Density $\left(\mathrm{kg} \mathrm{m}^{-3}\right)$ & Compressive strength in 28 day (MPa) \\
\hline 1 & 2310 & 10.0 & 2340 & 22.0 \\
2 & 2240 & 10.5 & 2360 & 22.5 \\
3 & 2330 & 10.0 & 2360 & 19.5 \\
4 & 2290 & 9.0 & 2280 & 20.5 \\
5 & 2320 & 10.5 & 2410 & 21.5 \\
6 & 2310 & 10.0 & 2360 & 22.5 \\
7 & 2320 & 10.0 & 2310 & 22.5 \\
8 & 2330 & 10.5 & 2360 & 22.0 \\
9 & 2360 & 11.0 & 2370 & 21.0 \\
10 & 2330 & 10.5 & 2390 & 22.5 \\
11 & 2370 & 10.0 & 2360 & 22.0 \\
12 & 2300 & 10.0 & & 22.0 \\
\hline
\end{tabular}

Table 8: Compressive strength test of concrete for the mixture $(1: 1.5: 3)$

\begin{tabular}{|c|c|c|c|c|}
\hline Sample No. & Density $\left(\mathrm{kg} \mathrm{m}^{-3}\right)$ & Compressive strength in 7 day (MPa) & Density $\left(\mathrm{kg} \mathrm{m}^{-3}\right)$ & Compressive strength in 28 day (MPa) \\
\hline 1 & 2410 & 26.2 & 2450 & 33.4 \\
\hline 2 & 2370 & 19.5 & 2430 & 28.9 \\
\hline 3 & 2380 & 21.6 & 2420 & 32.8 \\
\hline 4 & - & - & 2440 & 30.4 \\
\hline 5 & - & - & 2440 & 31.3 \\
\hline 6 & - & - & 2420 & 29.3 \\
\hline
\end{tabular}

Table 9: The percentages of the components of the Injana formation of the site of the study area

\begin{tabular}{|c|c|c|c|c|c|c|c|}
\hline \multirow[b]{2}{*}{ Locality } & \multirow[b]{2}{*}{ Slide No. } & \multirow[b]{2}{*}{ Total quartz } & \multirow[b]{2}{*}{ Feldpar } & \multicolumn{4}{|l|}{ Rock fragments } \\
\hline & & & & Sedimentray RF & Igneous RF & Metamorphic RF & Total RF \\
\hline & 2 & 43 & 1.3 & 55 & 0.6 & 0.1 & 55.7 \\
\hline & 4 & 60 & 1.1 & 38 & 0.7 & 0.2 & 38.9 \\
\hline & 9 & 52 & 1.5 & 45 & 0.7 & 0.8 & 46.5 \\
\hline & 13 & 50 & 1.2 & 48 & 0.7 & 0.1 & 48.8 \\
\hline
\end{tabular}

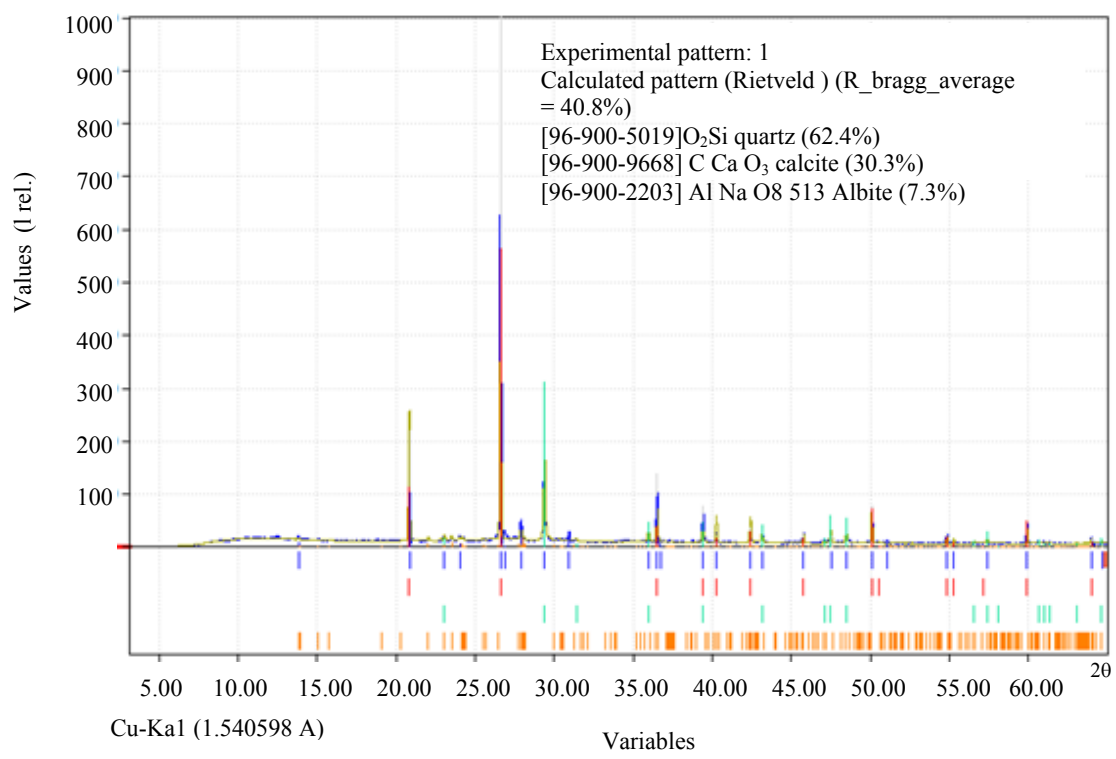

Fig. 6: X-ray diffraction pattern for bulk samples of the plant (7)

(BS., 2008) Table 7 and 8. The compressive strength of concert by the mixture $(1: 2: 4)$ at (7 days) range from the maximum value in $(11 \mathrm{MPa})$ in station No. 9 to the minimum value is ( $9 \mathrm{MPa})$ in station No. 4 Table 7 while the compressive strength of concert by mixture (1:2:4) at (28 days) range from the maximum value is $(22.5 \mathrm{MPa})$ in station No. $2,6,7,10$ to the minimum value is (19.5 MPa) in station No. 3 Table 7.
As for the mixture $(1: 1.5: 3)$ the compressive strength of concert at ( 7 days) ranges from the maximum value is (26.2) in station No. 1 to the minimum value is $(19.5 \mathrm{MPa})$ in station No. 2 while the compressive strength of concert ( 28 days) range from the maximum value is $(33.4 \mathrm{MPa})$ in station No. 1 to the minimum value $(28.9 \mathrm{MPa})$ in station No. 2 Table 7 (Fig. 6 and 7). 


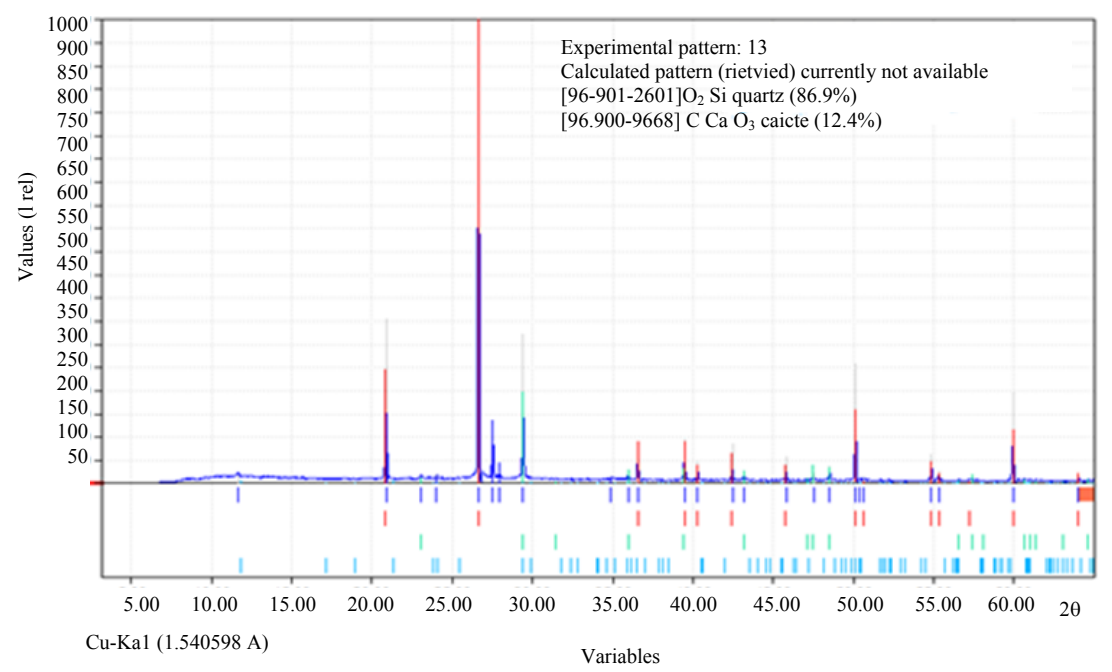

Fig. 7: X-ray diffraction pattern for bulk samples of the plant (12)

\section{Mineralogical tests include \\ X-Ray Diffraction (XRD) \\ Petrographic tests:}

Thin sections study: The components of the sandstone rocks were studied to Injana formation for selected samples from the Al-Qattara area and Al-Tar caves through the examination and study of (4) samples, Table 9 .

\section{CONCLUSION}

Based (COSQC., 1984) grain grading of sandstone powder of the samples conform to the fourth and third grading area. The specific gravity and absorption ratio of samples conform the requirement of (BS., 2012) and (COSQC., 1984). The soundness values range between (4.81-23\%) and are there for suitable for used in concert works. The compressive strength value for concrete cubes, according to the reference mixture $(1: 2: 4)$ for the (28 days) range between $(19.5,22.5 \mathrm{Mpa})$ and the mixture $(1: 1.5: 3)$ range between $(28.9,33.4 \mathrm{Mpa})$ and are there for good for used in concrete work.

The sulfate and gypsum contents for sandstone powder conform the requirement of (4) for concert industry.

The results of X-Ray diffraction of samples were analyzed showed the mineral content of the sandstone powder to be composed of the minerals quartz, gypsum, alpite and calcite. The petrographic study of sandstone powder classified as a lithoarenite.

\section{RECOMMENDATIONS}

It is recommended to study the impact of mix of coarse aggregate obtained from Dibdibba formation with powder sandstone of Injana formation in order to improve concert properties. It is a very necessary to used sulfate resistant cement for sandstone powder of the study area. It is recommended to treat of sulfate salts of sandstone powder for Injana formation by magnetic water technology. It is recommended to estimate the reserves of sandstone powder for Injana formation and the economic evaluate of sandstone rocks.

\section{REFERENCES}

ASTM., 2004. C-88-05 2004: Standard test method for soundness of aggregates by use of sodium sulfate or magnesium sulfate. ASTM International, West Conshohocken, Pennsylvania, USA. https://webstore.ansi.org/standards/astm/astmc8805

Ahamed, H.A., 2004. Stratigraphy and sedimentology of the Miocene succession-Karbala, Najaf area. MSc Thesis, College of Science, University of Baghdad, Baghdad, Iraq.

Al-Basrawi, N.H., 1996. [Hydrogeology of Razzaza Lake]. Ph.D Thesis, College of Science, University of Baghdad, Baghdad, Iraq. (In Arabic)

Al-Khateeb, A.A.G. and K.M. Hassan, 2005a. Detailed geological survey for mineral exploration in Karbala-Najaf area. GEOSURV, Australia.

Al-Khateeb, A.A.G. and K.M. Hassan, 2005b. Detailed geologyical survey for mineral exploration in Karbala-Najaf Area. GEOSURV-Iraq, Karradah, Baghdad, Iraq.

BS., 1990. Method of determination of organic matter, sulphat content and Gypsum in aggregate. Standards, London, UK.

BS., 2008. Compressive strength for cubesconcrete according to mix. British Standard, London, UK.

BS., 2012. Compressive strength of concrete cubes. British Standards. London, UK. 
Bieniawski, Z.T., 1975. The point-load test in geotechnical practice. Eng. Geol., 9: 1-11.

COSQC., 1984. Iraqi standard No 45 for the analytical analysis of thick and fine aggregates. The Central Organization for Standardization and Quality Control, Jadriyah, Baghdad, Iraq.
Hassan, A.H. and A.A.G. Al-Khateeb, 2004. Geological survey in Lissan Area in Karbala-Najaf Plateau. GEOSURV-IRAQ, Karradah, Baghdad, Iraq.

Hassan, K.M., 2007. Stratigraphy of Karbala-Najaf area, Central Iraq. Iraqi Bull. Geol. Min., 3: $53-62$. 